\title{
Upaya Pencegahan Stunting Melalui Pelatihan Kader Kesehatan Di Desa Gerbosari Kabupaten Kulon Progo
}

\author{
Nuryati $^{1 *}$, Dian Budi Santoso ${ }^{2}$, Angga Eko Pramono ${ }^{3}$ \\ ${ }^{1,2,3}$ Departemen Layanan dan Informasi Kesehatan, Sekolah Vokasi, Universitas Gadjah Mada \\ *Korespondensi: nur3yati@ugm.ac.id
}

\begin{abstract}
ABSTRAK. Stunting merupakan salah satu masalah kesehatan masyarakat yang menjadi prioritas pemerintah di bidang kesehatan. Hasil Riset Kesehatan Dasar (Riskesdas) 2018 menunjukkan bahwa kejadian stunting (pendek dan sangat pendek) di Indonesia sebanyak 30,8\% (11,5\% sangat pendek dan 19,3\% pendek) dan tahun 2019 menjadi sekitar 27\%, angka ini mengalami penurunan dari tahun 2013 dimana terdapat 37,2\% balita stunting (18\% sangat pendek dan 19,2\% pendek). Namun angka tersebut masih jauh dari target nasional dan WHO yaitu dibawah $20 \%$. Berdasarkan hasil analisis masalah bidang kesehatan di Desa Gerbosari ditemukan bahwa prevalensi stunting pada balita cukup tinggi dan pemahaman masyarakat terhadap stunting juga masih kurang. Oleh karena itu perlu dilakukan upaya pencegahan stunting pada balita melalui pelatihan kader kesehatan di Desa Gerbosari. Kegiatan kepada masyarakat ini bertujuan untuk meningkatkan pengetahuan dan pemahaman kader kesehatan mengenai stunting pada balita dan upaya pencegahannya. Kegiatan pelatihan dilaksanakan di Balai Desa Gerbosari secara bertahap untuk 105 kader kesehatan yang terbagi ke dalam 16 Posyandu. Kegiatan dilakukan dengan metode sosialisasi yang mencakup penyampaian materi, pemutaran video, dan diskusi. Capaian kegiatan pelatihan diukur menggunakan kuesioner evaluasi kegiaatan yang diisi oleh semua kader kesehatan di Desa Gerbosari, Kabupaten Kulon Progo. Dari hasil evaluasi diketahui bahwa mayoritas kader kesehatan telah memahami berbagai mitos dan fakta tentang stunting serta upaya pencegahannya.
\end{abstract}

Kata kunci: stunting, kader kesehatan, pencegahan

ABSTRACT. Stunting is one of the public health problems that is a priority for Indonesian Government in the health sector. The results of the 2018 Basic Health Research (Riskesdas) showed that the incidence of stunting (short and very short) in Indonesia was 30.8\% (11.5\% very short and $19.3 \%$ short) and in 2019 it was around $27 \%$, this figure experienced a decrease from 2013 where there were $37.2 \%$ stunted toddlers (18\% very short and $19.2 \%$ short). However, this figure is still far from the national and WHO targets, which are below $20 \%$. Based on the results of the analysis of health problems in Gerbosari Village, it was found that the prevalence of stunting in toddlers was quite high and public understanding of stunting was also still lacking. Therefore, it is necessary to prevent stunting in toddlers through training of health cadres in Gerbosari Village. This activity for the community aims to increase the knowledge and understanding of health cadres about stunting in children under five and its prevention efforts. The training activities were carried out at the Gerbosari Village Hall in stages for 105 health cadres which were divided into 16 Posyandu. The activity was carried out using a socialization method that included material delivery, video screenings, and discussions. The achievement of the training activities was measured using an activity evaluation questionnaire filled out by all health cadres in Gerbosari Village, Kulon Progo Regency. From the evaluation results, it is known that the majority of health cadres have understood various myths and facts about stunting and efforts to prevent it.

Keywords: stunting, health caders, prevention

\section{PENDAHULUAN}

Kesehatan merupakan hak asasi manusia yang harus dilindungi dan diperhatikan oleh pemerintah karena kesehatan merupakan salah satu indikator penting dalam menentukan kesejahteraan suatu bangsa selain faktor ekonomi dan sosial. Pengakuan itu tercantum dalam Deklarasi Perserikatan Bangsa -Bangsa tahun 1948 tentang Hak Azasi Manusia. Pasal 25 Ayat (1) Deklarasi menyatakan, setiap orang berhak atas derajat hidup yang memadai untuk kesehatan dan kesejahteraan dirinya dan keluarganya termasuk hak atas pangan, pakaian, perumahan dan perawatan kesehatan serta pelayanan sosial yang diperlukan dan berhak atas jaminan pada saat menganggur, menderita sakit, cacat, menjadi janda/ duda, mencapai usia lanjut atau keadaan lainnya yang mengakibatkan kekurangan nafkah, yang berada di luar kekuasaannya. Hal ini juga ditegaskan dalam Undang-Undang Dasar (UUD) tahun 1945 pasal $28 \mathrm{H}$ ayat 1, yang 
menyatakan bahwa setiap orang berhak memperoleh pelayanan kesehatan. Selain itu, Undang-Undang (UU) Nomor 36 tahun 2009 tentang kesehatan juga menjelaskan dengan tegas hak dan kewajiban pemerintah maupun masyarakat yang berkenaan dengan pemenuhan akan kesehatan.

Pembangunan kesehatan merupakan sebagai salah satu upaya pembangunan nasional untuk tercapainya kesadaran, kemauan dan kemampuan hidup sehat bagi setiap penduduk untuk mewujudkan derajat kesehatan optimal sebagai salah satu unsur kesejahteraan umum dalam tujuan nasional. Tujuan pembangunan kesehatan tersebut adalah terdapatnya kemampuan masyarakat untuk hidup sehat bagi setiap penduduk sehigga perlu upaya untuk meningkatkan akses masyarakat terhadap pelayanan kesehatan yang bermutu baik serta biaya yang terjangkau oleh masyarakat.

Pelaksanaan pembangunan kesehatan diarahkan untuk meningkatkan kesadaran, kemauan dan kemampuan hidup setiap orang agar terwujud derajat kesehatan masyarakat yang setinggi-tingginya. Untuk mewujudkan pembangunan kesehatan tersebut diselenggarakan upaya kesehatan dalam bentuk pencegahan penyakit, peningkatan kesehatan, pengobatan penyakit dan pemulihan kesehatan oleh pemerintah dan masyarakat yang dilaksanakan secara terpadu, terintegrasi dan berkesinambungan (Kemenkes RI, 2013). Salah satu masalah yang masih menjadi prioritas yaitu kekurangan gizi yang masih cukup tinggi terutama masalah pendek (stunting) pada balita.

Stunting dapat terjadi sebagai akibat kekurangan gizi terutama pada saat 1000 Hari Pertama Kehidupan (HPK). Stunting dalam jangka panjang berdampak buruk tidak hanya terhadap tumbuh kembang anak tetapi juga terhadap perkembangan emosi yang berakibat pada kerugian ekonomi. Salah satu cara mencegah stunting adalah pemenuhan gizi dan pelayanan kesehatan kepada ibu hamil. Upaya ini sangat diperlukan, mengingat stunting akan berpengaruh terhadap tingkat kecerdasan anak dan status kesehatan pada saat dewasa. Akibat kekurangan gizi pada 1000 HPK bersifat permanen dan sulit diperbaiki (Kementerian Kesehatan RI, 2018).
Anak stunting penyebab utamanya adalah asupan gizi (Young et al, 2019). Hasil penelitian menyebutkan bahwa faktor yang berperan penting dalam hal pertumbuhan fisik anak yaitu asupan gizi terkait factor social ekeonomi. Masyarakat, umumnya menganggap pertumbuhan fisik sepenuhnya dipengaruhi faktor keturunan. Pemahaman keliru itu kerap menghambat sosialisasi pencegahan stunting yang semestinya dilakukan dengan upaya mencukupi kebutuhan gizi sejak anak dalam kandungan hingga usia dua tahun. Oleh karena itu diperlukan sosialisasi berkesinambungan untuk meningkatkan pemahaman masyarakat mengenai masalah stunting pada balita.

Riskesdas 2018 menunjukkan bahwa kejadian stunting (pendek dan sangat pendek) di Indonesia sebanyak $30,8 \% \quad(11,5 \%$ sangat pendek dan 19,3\% pendek) dan tahun 2019 menjadi sekitar $27 \%$, angka ini mengalami penurunan dari tahun 2013 dimana terdapat $37,2 \%$ balita stunting (18\% sangat pendek dan $19,2 \%$ pendek). Namun angka tersebut masih jauh dari target nasional dan WHO yaitu dibawah 20\%. Desa Gerbosari merupakan salah satu desa tertinggal dengan nilai indeks 47.06 yang berada pada Pegunungan Menoreh sehingga kondisi geografisnya dilingkupi perbukitan dan kawasan hutan tropis. Masih ditemukan beberapa lokasi di Desa Gerbosari yang sulit untuk diakses sehingga menyebabkan perkembangan informasi juga terlambat. Berdasarkan hasil analisis masalah bidang kesehatan ditemukan bahwa prevalensi stunting pada balita cukup tinggi dan pemahaman masyarakat terhadap stunting juga masih kurang. Oleh karena itu dirasa perlu untuk melakukan upaya pencegahan stunting pada balita melalui pelatihan kader kesehatan di Desa Gerbosari.

\section{METODE}

Kegiatan pengabdian kepada msyarakat dilakukan pada bulan Agustus-Oktober 2021 di Desa Gerbosari. Solusi yang diterapkan terkait permasalahan kejadian stunting pada balita di Desa Gerbosari Samigaluh Kulon Progo yaitu dengan melakukan sosialisasi dan pelatihan kepada 105 kader kesehatan yang terbagi ke dalam 16 posyandu. Metode pelaksanaan yang digunakan dalam kegiatan 
sosialisasi pencegahan stunting balita di Desa Gerbosari yaitu sebagai berikut:

1. Penyuluhan, ditujukan kepada kader posyandu Desa Gerbosari. Materi penyuluhan disampaikan oleh 2 orang narasumber dan didampingi oleh 2 orang instruktur penyuluhan,

2. Pemutaran video terkait kejadian stunting yang bertujuan untuk memberikan gambaran kepada peserta,

3. Penjelasan terkait intervensi/penanganan balita stunting,

4. Diskusi dan tanya jawab antara narasumber dengan peserta,

5. Pre-test dan post-test untuk mengetahui ketercapaian penyampaian materi.

\section{HASIL DAN PEMBAHASAN}

Pertemuan rutin dengan para kader kesehatan di Desa Gerbosari rutin dilaksanakan secara setiap bulan. Pada pertemuan ini pihak Puskesmas dan Pemerintah Desa juga mengecek kelengkapan laporan pelayanan yang sudah disusun oleh masing-masing kader Posyandu termasuk pemantauan terhadap kondisi balita stunting. Dalam kegiatan rutin tersebut Tim Pengabdian kepada Masyarakat Sekolah Vokasi Universitas Gadjah Mada juga turut serta memberikan materi penyuluhan dan diskusi terkait penanganan kasus stunting.

\section{Penyampaian Materi}

Kegiatan penyampaian materi dilaksanakan dengan memberikan pertanyaan-pertanyaan pre-test kepada para kader kesehatan terkait dengan stunting. Sebagian kader masih belum dapat membedakan mitos dan fakta terkait dengan stunting.

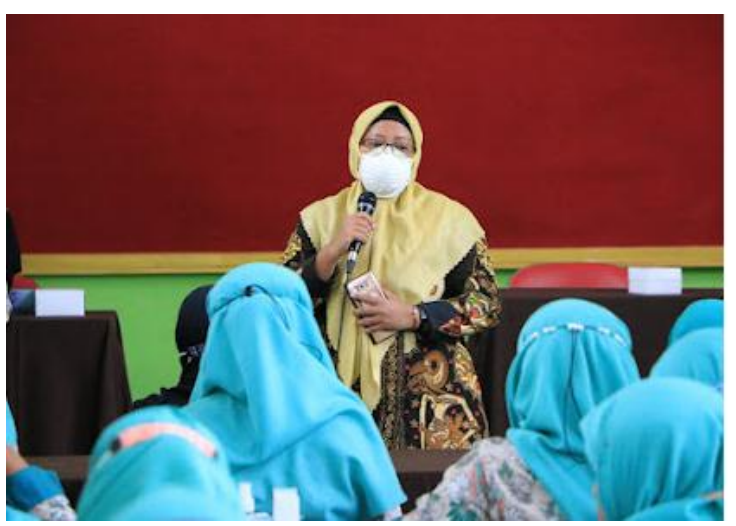

Gambar 1. Penyampaian Materi oleh Narasumber 1

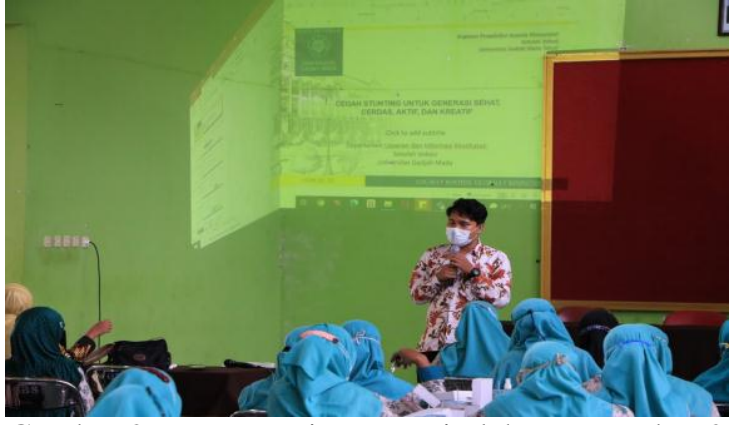

Gambar 2. Penyampaian Materi oleh Narasumber 2

\section{Mitos atau Fakta?}

1. Stunting disebabkan karena keturunan

2. Semua yang tinggi badannya pendek berarti stunting

3. Stunting disebabkan karena balita makannya hanya sedikit

4. Stunting terjadi sejak dalam kandungan (masa kehamilan)

5. Stunting berpengaruh pada perkembangan otak anak

6. Anak yang stunting sistem imunnya rendah sehingga mudah terserang penyakit

\section{UGM.AC.ID}

Gambar 3. Pre-Test terkait Mitos dan Fakta Stunting

Dari pertanyaan-pertanyaan pada Gambar 3 kemudian para kader kesehatan diarahkan ke materi selanjutnya terkait dengan strategi pencegahan dan pengananan stunting khususnya pada 1000 hari pertama kehidupan yaitu dari bayi dalam kandungan sampai dengan umur 2 tahun. Pengetahuan ibu, pola asuh, serta sanitasi lingkungan adalah faktor penting dalam terjadinya kasus stunting.

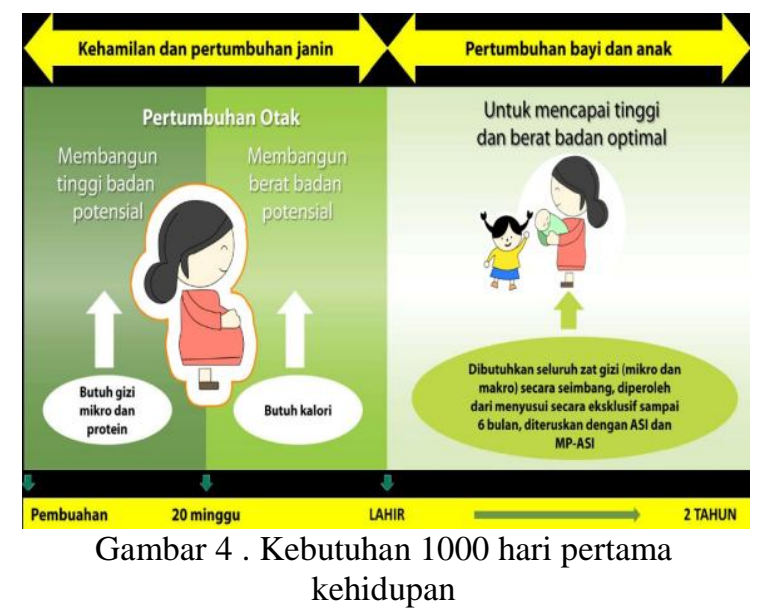

Stunting merupakan masalah serius yang mengancam generasi penerus bangsa, sehingga salah satu solusi untuk mengatasi dan mencegah masalah ini berkelanjutan, solusi 
yang ditawarkan adalah melalui metode pendampingan dan peningkatan kapasitas pengetahuan dari kader puskesmas.

Kejadian stunting pada balita di Desa Gerbosari sudah jauh berkurang, namun tetap menjadi perhatian baik kader maupun puskesmas. Perlu adanya pertemuan rutin dan disampaikan juga materi pencegahan stunting serta bimbingan kader untuk dapat mensosialisasikan ke masyarakat luas serta mendampingi balita atau keluarga yang memiliki kasus stunting. Hal tersebut selaras dengan hasil pengabdian masyarakat Azizah \& Wardhani (2020) bahwa solusi untuk permasalahan mitra kader posyandu dalam pencegahan stunting adalah melalui bimbingan kader balita sehat untuk mendapatkan infromasi tentang stunting, bagaimana cara mencegah, dan mensosialisasikan ke masyarakat luas.

\section{Diskusi}

Pada akhir sesi kegiatan penyampaian materi dilaksaakan kegiatan diskusi. Para kader antusias dengan materi yang diberikan. Beberapa hal yang menjadi fokus diskusi adalah bagaimana standarisasi pengukuran bayi di posyandu yang tentunya mempengaruhi akurasi pengukuran yang menjadi salah satu indikator dalam penentuan kasus stunting.

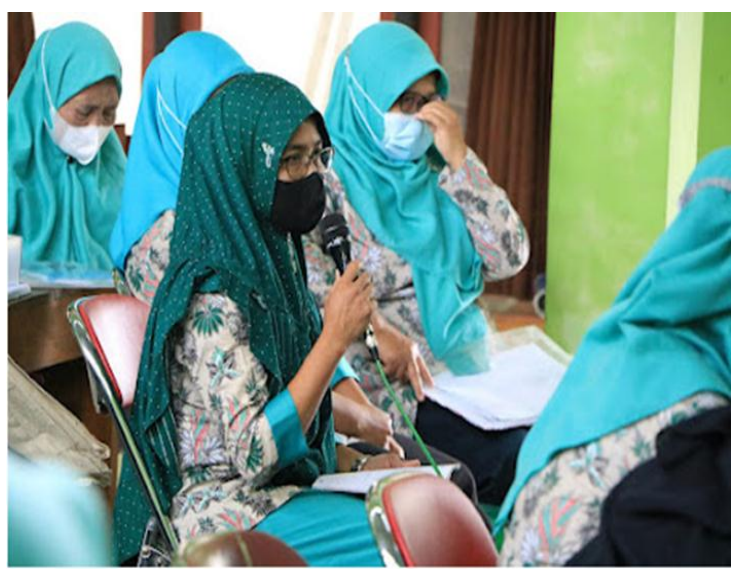

Gambar 5. Kegiatan diskusi dan tanya jawab

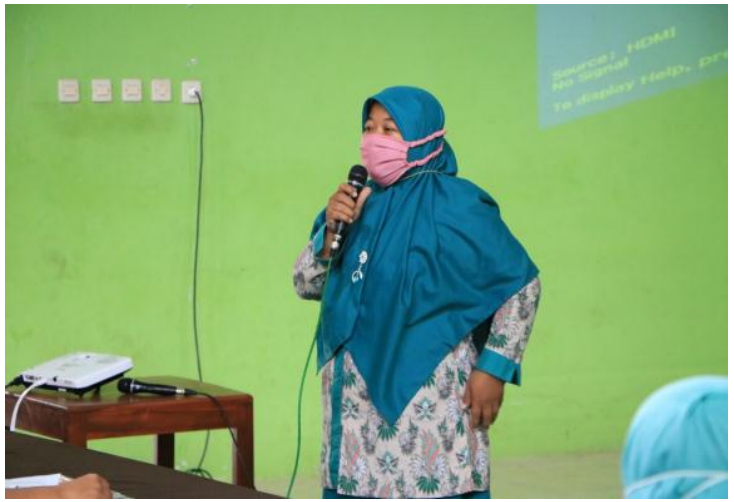

Gambar 6. Praktek bagi Kader dalam sosialisasi

Solusi lain dalam pemberian materi dan pelatihan serta demonstrasi tentang komponen gizi dalam rangka pencegahan stunting tidak hanya diberikan pada kader posyandu saja, akan tetapi juga melibatkan ibu-ibu yang memiliki balita. Hal tersebut sesuai dengan hasil pengabdian masyarakat Nurhidayati (2021) bahwa keterlibatan ibu-ibu yang memiliki balita dapat meningkatkan pengetahuan ibu serta mengurangi kesulitan kader dalam menjelaskan upaya pencegahan stunting di masyarakat. Selain itu hasil pengabdian masyarakat dari Hartono, et.all (2020) dalam pendampingan kader posyandu, selain memberikan materi terkait stunting juga diperlukan pendampingan dalam hal pengukuran antropometri anak secara mandiri, sehingga kader dapat lebih tepat mendeteksi anak balita yang beresiko mengalami stunting.

Selain kegiatan pendampingan untuk kader posyandu dalam hal edukasi, juga diperlukan kegiatan monitoring evaluasi status gizi dalam hal peningkatan berat bdan pada balita gizi kurang yang sudah mendapatkan proses pendampingan. Hal tersebut sesuai dengan hasil pengabdian masyarakat Jalpi, et.all (2020) bahwa kegiatan monitoring dilakukan melalui evaluasi membandingkan selera makan anak sebelum dan setelah pemberian produk, monitoring berat badan balita sebelum dan setelah pemberian produk, dihasilkan bahwa adanya kenaikan berat badan rata-rata $0.86 \mathrm{~kg}$ berat badan setelah pemberian produk. Hal tersebut cukup signifikan kenaikan berat badan balita, secara teori kenaikan dalam satu bulan minimal mendekati $1 \mathrm{~kg}$.

\section{Keberhasilan}

Berdasarkan hasil kuesioner evaluasi kegiatan (post-test), 94,2\% kader kesehatan telah 
memahami seputar mitos dan fakta stunting. Telah disepakati bersama bahwa kegiatan akan ditindaklanjuti dengan pendampingan pengelolaan stunting di masing-masing Posyandu yang memiliki balita stunting.

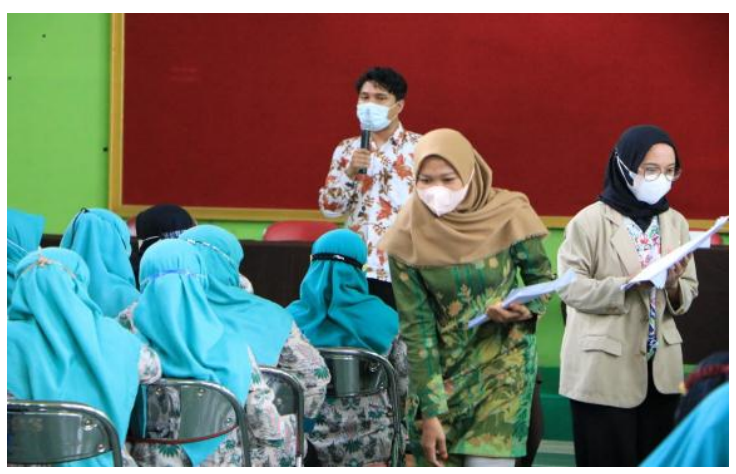

Gambar 7. Pembagian kuesioner evaluasi kegiatan

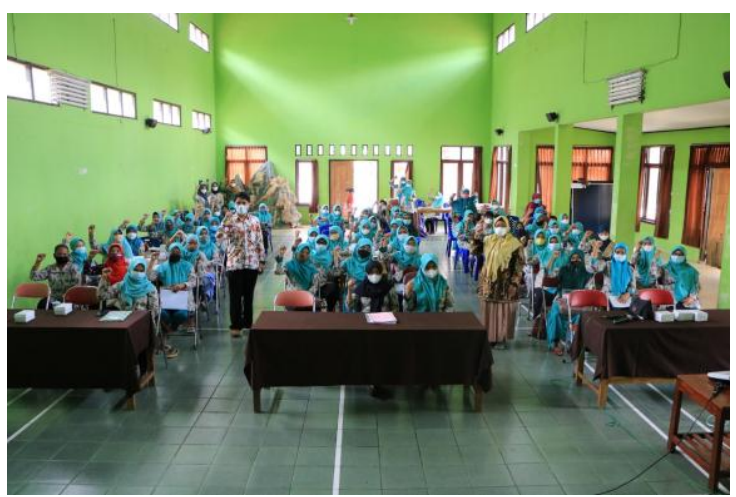

Gambar 8. Foto bersama dengan peserta pelatihan

Berdasarkan hasil pengabdian Suwarni, et.all (2020) dengan dilakukannya tahapan pendampingan kader relawan stunting di wilayah kerja Puskesmas Rasau Jaya Kalimantan Barat, didapatkan adanya peningkatan pengetahuan kader relawan stunting sebesar $70 \%$ serta kader merasakan manfaat terkait fungsi dan kaapsitas sebagai kader stunting serta mampu menjalankan tugas dan tangungjawabnya. Hal tersebut serupa dengan hasil pengabdian masyarakat dari Ramadhan, et.all (2021) bahwa metode penyuluhan kepada kader posyandu melalui video dapat meningkatkan pengetahuan kader sebesar $33 \%$.

\section{SIMPULAN}

Kegiatan pelatihan kader kesehatan telah dilaksanakan di Desa Gerbosari, Kabupaten Kulon Progo. Mayoritas kader kesehatan telah dapat menyerap materi dengan baik.

\section{UCAPAN TERIMAKASIH}

Terimakasih kepada Sekolah Vokasi Universitas Gadjah Mada yang telah mendanai kegiatan ini dan terimakasih kepada Kader Posyandu serta Pemerintah Desa Gerbosari yang telah memfasilitasi jalannya kegiatan pengabdian ini.

\section{DAFTAR PUSTAKA}

Azizah, E., \& Wardhani, R. (2020). Gerakan Kader Posyandu Sadar Stunting di Desa Ringinpitu Kecamatan Plemahan. Journal of Community Engagement in Health, 3(2), 229-232. https://doi.org/10.30994/jceh.v3i2.70

Hartono, R., Andini, M., Sartika, D., 2020. Peningkatan Kapasitas Kader Posyandu dan Edukasi Gizi pada Ibu Balita Dalam Pencegahan Stunting di Kleurahan Tamua Kota Makassar. Media Implementasi Riset Kesehatan, Vol 1, No 2. https://doi.org/10.32382/mirk.v1i2.1765

Jalpi, A., Rizal A., Fahrurazi, F., 2020. Pemberdayaan Kader Posyandu Terhadap Kejadian Stunting di Wilayah Kerja Kelurahan Sungai Miai Kota Banjarmasin. Jurnal Pengabdian Al-Ikhlas Universitas Islam Kalimantan Muhammad Arsyad Al Banjary, Vol 6, No

2.

http://dx.doi.org/10.31602/jpaiuniska.v6i2 .3897

Kementerian Kesehatan RI. 2018. Cegah Stunting itu Penting. Ditjen Kesmas. Retrieved from www.kesmas.kemenkes.go.id

Kementerian Kesehatan RI. 2011. Pedoman Pembinaan Perilaku Hidup Bersih dan Sehat (PHBS). Permenkes No. 2269/MENKES/PER/XI/2011: Jakarta.

Kementrian Kesehatan RI. 2013. Laporan Akuntabilitas Kinerja Kementrian Kesehatan Tahun 2013. Kemenkes RI: Jakarta.

Nurhidayati, E. (2021). Pendampingan Ibu Balita dan Kader Posyandu Balita Dalam Pencegahan Stunting di Desa Legung Kabupaten Sumenep. Darmabakti: Jurnal 
Indonesian Journal of Health Information Management Service (IJHIMS)

p-ISSN 2809-0462 (print) | e-ISSN 2809-0241 (online)

Vol. 1, No. 1, Bulan November 2021

Pengabdian Dan Pemberdayaan

Masyarakat, 2(1), 46-51.

https://doi.org/10.31102/darmabakti.2021.

$\underline{2.1 .46-51}$

Ramadhan, K., Maradindo, YE, Nurfatimah, N., Hafid, F. 2021. Kuliah Kader Sebagai Upaya Meningkatkan Pengetahuan Kader Posyandu Dalam Pencegahan Stunting. Jurnal Masyarakat Mandiri Vol 5, No 4. https://doi.org/10.31764/jmm.v5i4.5091

Suwarni, L., Selviana, S., Octrisyana, K., Vidyastuti, V., 2020. Pendampingan dan Peningkatan Kapasitas Kader Relawan
Stunting di Wilayah Kerja Puskesmas Rasau Jaya Kalimantan Barat. Jurnal Masyarakat Mandiri Vol 4 No, 2. https://doi.org/10.31764/jmm.v4i2.2017

Young, M.F., Nguyen, P.H., Cassanova, I.G., Ado, O.Y., Tran, L.M., Nguyen, S., Martorell, L., Ramakhrisnan, U. 2018. Role of maternal preconception nutrition on off spring growth and risk of stunting across the first 1000 days in Vietnam: A prospective cohort study. Plos One. 